\title{
Pesantren Dan Homoseksualitas Kaum Santri (Studi Pada Pesantren Tua Salafiyyah dan Khalafiyyah di Kota Santri Jawa Timur)
}

\author{
Azam Syukur Rahmatullah, Muhammad Azhar \\ Universitas Muhammadiyah Yogyakarta Indonesia \\ azam.sy@umy.ac.id,muazar@yahoo.com
}

\begin{abstract}
The research has the effort to know a behavior of LGBT in Pesantren. The assumption until now, Pesantren was innocent and be the free zone of LGBT. This research is using qualitative and ethnomethodology' approach. The location of research is in Pesantren Salafiyyah Kyai Kholil Bangkalan Madura, that old Pesantren Salafiyah in Madura. The other Pesantren is Pesantren Al-Hikam Bangkalan Madura that old Pesantren Khalafiyah in Madura. The results of research are; First, kinds of behavior that indicate LGBT in Pesantren are (1) kakak-adikan, kobel, mojok, kelon. The Second, the efforts from two pesantren are same handling based cognitive, spiritual and physical. The handling in Pesantren Salafiyyah Kyai Kholil Bangkalan, are three enhance; (1) period beginning of kesantrian (2) period of unification santri (3) period the end of kesantrian. The handling in Pondok Pesantren Al-Hikam with several methods; (1) assessment of kitab method (2) punishment method (3) counseling method (4) assessment and enlightenment method (5) supervision without served.
\end{abstract}

Keywords: homoseks santri, old of pesantren, ethnomethodology

\begin{abstract}
Abstrak
Penelitian ini berupaya untuk mengungkap perihal perilaku yang terindikasi homoseks yang ada di Pesantren, sesuatu yang selama ini diasumsikan pesantren itu "bersib" dan "terbebas" dari virus-virus LGBT. Penelitian ini merupakan penelitian kualitatif dengan pendekatan etnometodologi. Lokasi penelitian di Madura yang berpusat di Pondok Pesantren Salafiyyah Kyai Kholil Bangkalan, yang merupakan Pondok Pesantren Tua Salafiyah. Sedangkan, pesantren lainnya adalah Pondok Pesantren Al-Hikam Madura, yang merupakan Pesantren Tua Khalafiyyah. Hasil dari penelitian ini; Pertama, Perilakuperilaku yang berkecenderungan mengarah pada virus homoseks santri di antaranya adalah; kakak-adikan, kobel, mojok, kelon. Kedua, upaya penanganan yang dilakukan dua pesantren tersebut pada substansinya sama yakni penanganan berbasis kognitif, spiritual, dan fisik. Penanganan di Pesantren Salafiyyah Kyai Kholil Bangkalan, meliputi tiga tingkatan, yakni, masa awal kesantrian, masa penggemblengan santri, dan masa akhir kesantrian. Sedangkan di Pesantren Al-Hikam penanganannya dengan beberapa metode; metode pengkajian kitab, hukuman., konseling, pengkajian dan pencerahan jiwa dan pengawasan tanpa putus.
\end{abstract}

Kata kunci; Homoseks santri, Pesantren Tua, Etnometodologi

Permalink/DOI: http://dx.doi.org/10.18326/infsl3v12i2.457-480 


\section{Pendahuluan}

Pada dasarnya isu tentang Lesbian, Gay, Biseksual dan Transgender (selanjutnya disingkat LGBT atau Homoseksual) bukanlah isu baru, di kawasan negara Barat tema-tema kajian tentang homoseksual sudah sejak lama dikaji. Hal ini disebabkan di negara barat, perilaku homoseksual bukan dianggap menyimpang, tetapi merupakan perilaku yang lumrah. Sebagai bukti adanya negara-negara yang terang-terangan melegalkan hubungan sejenis, baik dalam konteks masa berpacaran yang ditunjukkan dalam ruang terbuka (publik) maupun ruang tertutup (privat), serta dalam bentuk pernikahan sejenis. Menurut berita yang dilansir oleh liputan6.com bahwa sudah ada 23 negara yang menghalalkan pernikahan sejenis yang hampir sebagian besarnya didominasi oleh negara barat (www. news.liputan6.com, yang diakses pada tanggal 12 Februari 2016). Bahkan negara Amerika Serikat pada akhirnya ikut mendukung dan melegalkan pernikahan sejenis, yang menjadikannya sebagai negara Barat terakhir yang menghalalkan pernikahan sejenis tersebut, yakni pada hari Jumat tanggal 26 Juni 2015 (www.kompasiana.com diakses pada tanggal 12 Februari 2016).

Berbeda dengan kawasan negara barat, untuk negara timur secara umum masih memandang bahwa hubungan sesama jenis merupakan perilaku yang menyalahi kodrat, perilaku yang menyimpang dari norma agama maupun adat istiadat. Beberapa dalil yang digunakan adalah QS. Asy-Syu'ara ayat 165-166, yang mempertanyakan tentang "kemengapaan mendatangi sesama lakilaki, dan meninggalkan istri-istri yang sudah ada." Ayat lain yakni pada QS. Al'A'raf ayat 80-82 yang menegaskan bahwa mereka yang melakukan hubungan sejenis adalah kaum yang melampaui batas. Serta QS. Al-Hijr ayat 72-75 yang memberikan gambaran tentang "kepastian akan hukuman/azab bagi pelaku-pelaku hubungan sejenis.

Meskipun tidak terlihat frontal atau terang-terangan, tetapi sesungguhnya gerakan atau arus percintaan sejenis di negara timur khususnya di Indonesia tetap berjalan. Para kaum homoseksual tetap melakukan hubungan-hubungan underground, dan mereka belum berani menampakkan diri secara terang-terangan di 
hadapan publik; dalam arti belum berani menampakkan perilaku seksnya di hadapan umum, belum berani menyuarakan kepada pemerintah untuk melegalkan pernikahan sejenis, atau belum berani memperkenalkan pasangan sejenisnya kepada orang tua atau masyarakat sekitar. Hal ini disebabkan sempitnya ruang pengakuan dan belum diterimanya "budaya cinta sejenis" di kawasan negara Timur terutama kawasan Indonesia. Namun secara perlahan mereka sudah mulai menunjukkan eksistensi mereka pada ruang media sosial (medsos), sebagai bukti nyata sudah maraknya group-group yang berlatar homoseksual baik di media Facebook, Tweeter atau instagram. Kondisi yang demikian tentunya mengkhawatirkan dan perlu disikapi serta diminimalisir kemunculannya sejak dini, agar kedepannya tidak menjadi boomerang bagi diri mereka sendiri dan masyarakat umum.

Salah satu institusi Pendidikan yang cukup riskan dengan keberadaan isu homoseksual adalah lembaga pesantren. Lembaga pesantren merupakan lembaga yang memiliki beragam santri dengan latar belakang berbeda-beda; latar belakang kepribadian, latar belakang kematangan atau tidaknya seksualitas diri, latar belakang keluarga dan segala problematikanya, latar belakang pendidikan, yang kesemuanya tinggal dalam satu kompleks kepesantrenan. Kondisi yang demikian diperkuat dengan "dipisahkannya" antara santri putri dan santri putra, umumnya dalam bentuk pemisahanjarak pondok, meskipun tetap dalam satu area yang luas. Artinya, santri putra dan putri dipisah dengan jarak yang cukup jauh/tidak berdekatan, tetapi masih di dalam satu area pesantren. Sehingga menyebabkan dipisahkannya ruang kelas, tidak dicampur antara santri putri dan putra.

Adanya pemisahan-jarak dan pemisahan kelas antara putra dan putri, ditambah lagi adanya sanksi bagi santri putra dan putri yang bertemu-muka atau diketahui berpacaran, atau adanya larangan membawa alat komunikasi, serta adanya berbagai latar belakang santri yang berbeda-beda di atas, dan kegiatan keseharian yang menuntut untuk bertemu dan bersosialisasi dengan sesamanya (sesama kaum laki-laki dan sesama kaum perempuan) secara terus menerus tanpa adanya kebolehan untuk bersosialisasi dengan lawan 
jenis, menjadikan kaum santri riskan/rawan terjangkiti penyakit seksual menyimpang yang dalam hal ini "percintaan sejenis". Terlebih lagi masa mereka yakni kaum remaja sejatinya masa yang sedang berkembang kejiwaan, naluri seksual dan hormonalnya, dan umumnya sedang mencari "identitas jati diri (Maurice J. Elias,dkk, 2003)."

Adanya istilah mairil(Yuli Kamiasari: 2011)dan dallaq(Zaifudin Zuhri: 2007) dan berbagai penelitian tentang homoseksualitas di Pesantren (Usman: 2012) serta berbagai penyebabnya semakin memperkuat adanya realita bahwa di Pesantren memang rawan terjangkiti virus homoseksual (Iskandar Zulakarnaen:2006). Pesantren menjadi salah satu institusi Pendidikan Islam yang perlu meningkatkan kewaspadaannya(Nailil Rohmah:2011).

Oleh karena itulah dalam hal ini peneliti berupaya untuk menggali lebih dalam perihal upaya-upaya yang dilakukan oleh para kyai di Pesantren Salafiyyah dan Khalafiyyah untuk meminimalisir perilaku homoseksual tersebut. Sengaja peneliti melakukan penelitian ini di Kota Santri Jawa Timur, yang dalam hal ini adalah kota Madura, hal ini dikarenakan Jawa Timur merupakan "kota seribu pesantren" karena begitu banyaknya pesantren yang ada di Jawa Timur, baik pesantren salafiyyah, khalafiyyah ataupun kombinasi. Dengan banyaknya pesantren itulah yang menjadikan dasar pemilihan lokasi penelitian, yang nantinya akan diambil sampel Beberapa pesantren tua baik salafiyyah maupun khalafiyyah, yang natinya kebijakan, program, dan langkah-langkah dan upaya peminimalisiran dari virus homoseksual oleh sang kyai dapat dijadikan media percontohan, dan permodelan bagi pesantren-pesantren lainnya, baik di wilayah Jawa Timur maupun di luar Jawa Timur .

\section{Metode Penelitian}

Penelitian ini merupakan penelitian lapangan (field research) sehingga prinsip yang digunakan adalah prinsip-prinsip penelitian lapangan, dengan menggunakan metode kualitatif dengan alasan gejala yang diteliti merupakan gejala interaksi edukatif 
yang dinamis. Pendekatan penelitian yang digunakan adalah pendekatan etnometodologi, yakni salah satu cabang keilmuan yang berhubungan erat dengan dunia kehidupan (lebenswelt) dari individu atau masyarakat. Dengan pendekatan etmonetodologi ini dimaksudkan untuk mengetahui lebih dalam tentang fakta sosial yang ada dan terjadi di masyarakat. Penelitian ini dilakukan di beberapa pesantren tua salafiyyah dan khalafiyyah di daerah Jawa Timur. Kategori tua yang dimaksud peneliti adalah minimal berusia 20 tahun, yang tentunya memiliki banyak pengalaman yang berhubungan dengan pengelolaan baik dalam bidang kesantrian maupun pengembangan kepesantrenan. Rencana awal pesantren yang akan dituju-adalah Pondok Pesantren Al-Hikam Bangkalan Madura, yang berumur lebih dari 20 tahun. Pondok ini mewakili dari kalangan pesantren khalafiyah. Kemudian Pondok Pesantren Salafiyah Kyai Kholil Bangkalan Bangkalan Madura yang mewakili dari pesantren jenis salafiyyah, yang berumur lebih dari 50 tahun.

\section{Hasil Penelitian}

Perilaku-perilaku Berkecenderungan Homoseksual Santri di Dua Pesantren Tua Bangkalan Madura

Berdasarkan hasil pengamatan, wawancara mendalam dan survey lapangan, hasil penelitian menyatakan bahwa pada kedua pesantren tua salafiyyah dan khalafiyyah, yakni di Pondok Pesantren Salafiyah Kyai Kholil Bangkalan Madura dan Pondok Pesantren AlHikam Bangkalan Madura, dijumpai beberapa hal yang sama. Salah satu kesamaannya adalah adanya perilaku-perilaku santri yang terkadang nganeb-nganebi. Perilaku yang berkencenderungan para santri melakukan tindakan-tindakan yang dikhawatirkan akan mengarah pada perilaku homoseksual. Meskipun dari kedua lapangan ditemukan bahwa tindakan-tindakan yang nganehnganehi tersebut, belum sampai pada tahapan yang "mengerikan". Dengan kata lain, tindakan para santri di dua pesantren tersebut masih dalam batas ringan namun tetap perlu mendapatkan perhatian khusus dan penanganan sejak dini. 
Ada beberapa alasan munculnya perilaku yang nganebnganehi santri yakni perilaku yang berkecenderungan homoseksual. Beberapa alasan yang dimaksud adalah: Pertama, alasan klasik, yang menyatakan bahwa "semua santri laki-laki, atau semua santri perempuan", sehingga karena tidak pernah berkomunikasi dengan santri perempuan, terkadang santri putra dijadikan "seolah-olah" sebagai santri putri, dan pula sebaliknya, meskipun hal yang demikian terkadang hanya untuk permainan belaka, atau "isengisengnya kaum santri”. Kedua, masa-masa remaja yang secara naluri ingin mengenal lebih wanita, atau sebaliknya namun terhalang oleh dinding pemisah yang kuat— karena di area pesantren — terkadang menjadikan mereka "bertingkah yang aneh-aneh," sebagai bentuk pelampiasan karena tidak berhubungan langsung dengan santri perempuan atau sebaliknya. (Wawancara dengan ustadz Farid Tumyadi, Ketua Ma'had Bidang Ubudiyah Pondok Pesantren Salafiyah Al-Kholil Bangkalan, Madura tanggal 10 Mei 2018)

Ustadz Farid Tumyadi salah satu dewan asatidz senior di Pondok Pesantren Salafiyah Kyai Kholil Bangkalan menegaskan alasan mengapa seringnya kemunculan perilaku-perilaku yang terkesan mengarah pada perilaku homoseks di kalangan santri. Salah satu di antaranya adalah karena faktor aturan-aturan yang ketat dan kuat dari pesantren, yang membatasi pergaulan dengan santri putri. Hal ini dengan alasan kuat, agar tidak terjadinya hubungan-hubungan terlarang antara kaum adam dan hawa di pesantren, suatu hal yang masih tabu terjadi di kalangan santri (Wawancara dengan ustadz Farid Tumyadi, Ketua Ma'had Bidang Ubudiyah Pondok Pesantren Salafiyah Al-Kholil Bangkalan, Madura tanggal 10 Mei 2018). Meski pada akhirnya, pembatasan yang kuat ini menjadikan para santri putra maupun putri terkadang "guyonan" dengan menjadikan kawan sebayanya sebagai pihak santri putrinya. Namun hal yang demikian hanya sebatas bercandaan, bukan sesungguhnya. Demikian pula, tatkala tidur kemudian "kelonan", menurut ustadz, hal itu wajar saja, yang penting tidak mengarah yang berlebihan, dan mengarah pada penyimpangan. 
Hal yang demikian di atas bisa saja terjadi, karena jumlah santri yang sedemikian banyak, sehingga tidak mungkin akan memantau mereka 24 jam. Sehingga, bisa saja di waktu-waktu "lengah" mereka melakukan aksinya. Namun untuk yang nampak di mata, tidak ada perilaku homoseks yang berat, seperti hubungan seksual sesama jenis di pesantren (Wawancara dengan ustadz Farid Tumyadi, Ketua Ma'had Bidang Ubudiyah Pondok Pesantren Salafiyah Al-Kholil Bangkalan, Madura tanggal 10 Mei 2018)

Adapun di Pondok Pesantren Al-Hikam Bangkalan yang notabene memiliki karakteristik berbeda dengan pesantren Kyai Kholil Bangkalan, dimana letak perbedaannya adalah jika pesantren Kyai Kholil Bangkalan berjenis pesantren yang antara pesantren putra dan putri berjauhan "tidak tinggal satu tempat, dan pembelajaran yang sendiri-sendiri”, sehingga menyebabkan kemunculan perilaku santri yang nganeh-nganehi. Lain halnya dengan Pesantren alHikam yang antara lokasi santri putra dan putri tinggal dalam satu area, dan terpusat langsung di dampingi oleh Sang Kyai. Meski begitu perilaku nganeh-nganehi kenyataannya tetap ada, meski berskala ringan.

Kyai Fathurrohim Abdur Rahman menyatakan bahwa pihak pesantren tidak menutup mata, bahwa ada faktor-faktor lain yang menjadikan seseorang menyimpang dan berperilaku cenderung homo, selain faktor aturan ketat dan berjauhannya antara asrama putra dan putri (Wawancara dengan Kyai Fathurrohim Abdur Rahman, di Pondok Pesantren al-Hikam, Bangkalan Madura, tanggal 15 Mei 2018). Ada faktor-faktor lain yang mungkin ada di antara para santri, salah satunya adalah faktor bawaan sebelum masuk pesantren. Di mana mereka memang sudah memiliki jiwajiwa suka sejenis, sehingga tatkala di pesantren yang memang satu jenis, sakit dan penyakitnya semakin meluas dan bahkan akan bisa mempengaruhi santri-santri lain.

Berdasarkan dari pemaparan di atas dapatlah dibuat tabel beberapa perilaku yang nganeh-nganehi yang berkecenderungan homoseks santri di dua pesantren tersebut antara lain; 
Tabel 1. Perilaku Nganeh-nganehi Santri yang Berkecenderungan Homoseks Santri di Pesantren Salafiyah al-Kholiliyah Bangkalan

\begin{tabular}{|c|c|}
\hline $\begin{array}{l}\text { Perilaku yang } \\
\text { ditunjukkan }\end{array}$ & Keterangan \\
\hline \multirow[t]{3}{*}{$\begin{array}{l}\text { Kakak adik, } \\
\text { kakak-adikan }\end{array}$} & $\begin{array}{l}\text { - Hal yang menunjukkan adanya hubungan afeksi } \\
\text { yang tinggi antara seorang senior dan yunior. }\end{array}$ \\
\hline & $\begin{array}{l}\text { - Umumnya santri senior mencari santri yunior } \\
\text { yang sesuai di hati, dan secara fisik tidak ngisin- } \\
\text { ngisini (alias tidak memalukan secara fisik) }\end{array}$ \\
\hline & $\begin{array}{l}\text { - Hubungan kedekatan tersebut masih pada } \\
\text { batas-batas yang wajar, pergi berdua, tingkat } \\
\text { keseringan bertemu yang tinggi, kemana-mana } \\
\text { bersama, namun tidak mengarah pada hubungan } \\
\text { seks yang sebagaimana kaum homoseks di luar } \\
\text { pesantren, }\end{array}$ \\
\hline
\end{tabular}

- Artinya hubungan yang dikatakan perilaku homoseks santri masih pada batasan-batasan yang wajar. Sebagai bukti pesantren tidak pernah menemukan santri yang sampai pada tahapan hubungan intim sejenis.

Tidur kelon sesama santri
- Tidur kelon umumnya yang dilakukan oleh para santri adalah tidur dengan kaki yang menumpang ke tubuh santri lain.

- Dengan kondisi satu kamar dengan banyak santri, dan dengan kondisi tidur yang terkadang "tanpa sadar" kaki yang terkesan "mengeloni" kawannya. Mungkin yang demikian banyak terjadi di pesantren. Namun kata ustdaz Achmad Hafsin bukan mengarah pada kelon karena suka sesama jenis (Wawancara dengan ustadz Achmad Hafsin, Sekretaris Ma'had Pondok Pesantren Salafiyah AlKholil Bangkalan, Madura tanggal 10 Mei 2018). Namun kelon dalam batasan-batasan wajar. Sedangkan kelon yang dalam artian "perilaku homoseks" menurut Ustadz tidak dijumpai di Pesantren Salafiyah Kyai Kholil Bangkalan. Sebagai buktinya, tidak ada dari mereka yang selama ini ditemukan kelon dan bercumbu sesama jenis. 
Kobel terhadap santrisantri yang dikategorikan tampan, bagus dan kulit bersih. Atau apabila santri putri kepada santri putri yang cantik dan manis.
- Kobel merupakan perilaku yang kadang dilakukan karena faktor gemes (mean: benarbenar ingin mencubit karena lucu, imut, manis) kepada santri-santri dibawahnya yang berwajah menggemaskan. Hal yang demikian kata ustdaz Hafsin sesuatu yang wajar saja, asalkan tidak berlebihan sampai mencium pipi dan sebagainya. Selama masih pada koridor yang pantas, tidak menjadi masalah, karena Hal yang demikian hanya merupakan ungkapan kekaguman kepada fisik adik yuniornya. Hal yang demkian pula tentunya di Pesantren Salafiyah Kyai Kholil Bangkalan pernah terjadi, atau sering terjadi tetapi sekali lagi hanya sebatas kekaguman semata. Namun untuk yang lebih dari itu, tidak ada. Demikan yang disampaikan oleh ustadz Hafsin (Wawancara dengan ustadz Achmad Hafsin, Sekretaris Ma'had Pondok Pesantren Salafiyah Al-Kholil Bangkalan, Madura tanggal 10 Mei 2018).

Menurut Ustadz Farid, sampai hari ini tidak ada dan belum pernah dijumpai santri yang mendapatkan hukuman karena berhubungan badan dengan sesamanya, baik santri putri maupun putra selama belajar di pesantren (Wawancara dengan ustadz Farid Tumyadi, Sekretaris Ma'had Salafiyah Al-Kholil Bangkalan, Madura tanggal 10 Mei 2018). Meski "kewaspadaan" terus ditingkatkan. Hal tersebut dikarenakan pesantren tidak menutup mata, bahwa perkembangan teknologi yang semakin canggih, utamanya teknologi visual, dan media online dan juga penurunan akhlak kaum muda yang semakin memprihatinkan, dikhawatirkan akan ikut merasuki para kaum pesantren, apalagi terkait fenomena homoseksual yang sedang marak. Oleh karena itulah kewaspadaan kepada kaum santri menjadi modal besar. 
Hal senada juga disampaikan oleh pengurus kamar yakni saudara Ahmad Hambali yang menyatakan bahwa memang diakui beberapa kasus yang seolah-olah menjurus ke arah perilaku homoseks itu ada, seperti kasus adek-adekan, atau kelon, dan kobel namun yang demikan bukan semata-mata itu adalah percintaan sejenis (Homoseksual) tentu bukan. Hal yang demikian hanya batas wajar, dam tidak ada yang mengarah ke homoseksual (Wawancara dengan Ahmad Hambali, pengurus kesantrian di Pondok Pesantren Al-Kholil Bangkalan Madura, tanggal 11 Mei 2018)

Hal senada juga dinyatakan oleh pengurus kamar santri putri, yang mengatakan bahwa selama ini belum dijumpai perilakuperilaku homoseks yang berat, seperti hubungan kelamin di pesantren. Meski kalau untuk perilaku-perilaku ringan, seperti adikadikan tentu yang demikian ada. Perilaku berduaan, yang kemanamana berbarengan tentu juga ada. Apalagi untuk santri putri akan sangat sulit mendeteksi apa mereka berperilaku menyimpang atau tidak, karena umumnya santri putri memang sangat umum dan lazim membangun hubungan afeksi antara sesamanya. Misalkan bergandengan tangan, berpelukan, hal-hal yang demikian adalah kelaziman antara sesama putri (Wawancara dengan Aisyawati, pengurus kesantrian di Pondok Pesantren Al-Kholil Bangkalan Madura, tanggal 11 Mei 2018).

Meskipun demikian, para pengurus santri putri tetap "tidak lengah", justru terkadang karena kelaziman itulah yang pada akhirnya para pengurus santri putri meningkatkan kewaspadaan. Mereka juga menyadari bahwa santri banyak pasti bisa membawa perilaku yang beraneka ragam, sehingga para pengurus harian, dan kamar tetap menjaga agar perilaku tidak menyimpang (Wawancara dengan Aisyawati, pengurus kesantrian di Pondok Pesantren AlKholil Bangkalan Madura, tanggal 11 Mei 2018).

Sedangkan pada Pesantren Al-Hikam Bangkalan Madura beberapa perilaku yang nganeh-nganehi terlihat pada tabel berikut ini: 


\section{Tabel 2. Perilaku Nganeh-nganehi Santri yang Berkecenderungan Homoseks Santri di Pesantren Al-Hikam Bangkalan}

\section{Perilaku yang Menjurus Ke Arah Homoseks Santri

\author{
Keterangan
}

Kobel (mencolek pipi) kepada santri yunior

Mojok berdua antara dua santri

Kobel ini biasanya dilakukan kepada santri-santri yunior karena faktor gemes (gregetan), karena terlalu manis, cakep, dan mempesona. Selain itu juga karena santri yunior berkulit putih, dan memiliki aura yang menjadikan santri senior ingin mendekatinya. Kondisi yang demikian banyak terjadi di lingkungan pesantren. Bedanya, kobel yang sering dilakukan sebetulnya bukan kobel karena nafsu tetapi hanya rasa geregetan karena ketampanan tersebut. Demikian pula yang terjadi di Pesantren ak-Hikam kobel karena gemes dan geregetan memang sering kali dilakukan oleh kakak senior kepada yunior, perilaku yang merupakan tanda kekaguman akan ketampanan sang adik yunior (Wawancara dengan Ustadz Abdul Basith, di Pengrus Kesantrian Pondok Pesantren alHikam, Bangkalan Madura, tanggal 16 Mei 2018).

Mojok berdua menurut Ustdaz Abdul Basith sebetulnya merupakan akivitas yang banyak dilakukan santri (Wawancara dengan Ustadz Abdul Basith, di Pengrus Kesantrian Pondok Pesantren al-Hikam, Bangkalan Madura, tanggal 16 Mei 2018 ). Namun dalam hal ini mojok berdua tersebut hanya sebatas perkawanan saja, tetapi tidak sampai mengarah pada perilaku yang anehaneh, dan mengarah pada percintaan sejenis. Hal ini dikarenakan banyak santri yang membutuhkan sahabat karib yang ke mana-mana bersama-sama. Dengan demikian mojok disini bukan pada ranah mojok karena nafsu ingin melampiaskan libidonya.

Menurut pengamatan Ust. Abdul Basith dikarenakan di Pesantren Al Hikam setiap hari santri putra maupun putri bisa bertatap muka, karenanya sangat sedikit terindikasi adanya mojok karena percintaan sejenis (Wawancara dengan Ustadz Abdul Basith, di Pengurus Kesantrian Pondok Pesantren al-Hikam, Bangkalan Madura, tanggal 16 Mei 2018). 
Tidur kelon alias kaki Menurut Rahman sebagai pengurus kamar, menempel di tubuh kawan sampingnya yang sama-sama sedang tidur menyatakan bahwa sebetulnya seorang santri ketika tidur kaki menempel di tubuh kawannya itu hal biasa di Pesantren al-Hikam ini. Hal tersebut dikarenakan banyaknya santri dalam satu kamar, dengan gaya tidur yang beragam (Wawancara dengan Rahman pengurus kamar santri Pondok Pesantren al-Hikam, Bangkalan Madura, tanggal 16 Mei 2018). Manakala menjumpai santri yang menempelkan kaki dan tangannya ke santri lain, itu bukan berarti adanya hubungan percintaan sejenis, tetapi memang hanya sebatas perilaku tidur yang tanpa sadar.

Hal yang demikian pula ditegaskan oleh Jalaludin pengurus kamar lainnya yang menyatakan bahwa sampai hari ini tidak ada santri yang mengeloni kawan lain karena memang nafsu, kalau tokh ada pun hanya sebatas main-main atau guyonan santri saja (Wawancara dengan Jalaludin pengurus kamar santri Pondok Pesantren al-Hikam, Bangkalan Madura, tanggal 16 Mei 2018).

Kakak-adikan

Menurut pengurus kamar Jalaludin memang harus diakui "ada saja" para santri yang memiliki perkawanan lebih dari sekedar kawan. Artinya, ada di antara mereka yang menciptakan hubungan antara adik dan kakak. Hal demikian harus diakui terjadi. Namun apakah antara kakak dan adik "palsu" tersebut ada hubungan percintaan sejenis (Wawancara dengan Jalaludin pengurus kamar santri Pondok Pesantren al-Hikam, Bangkalan Madura, tanggal 16 Mei 2018). Menurut pengurus kamar Rahman hal tersebut yang sampai sekarang belum ada bukti nyatanya.Sepengetahuan kami sebagai pengurus kamar, ya hanya sebatas kakakadik saja, misal; saling membantu, saling mensupport, dan saling mendukung satu sama lainnya saja. Namun jika di belakang kami ternyata ada hubungan sejenis, tentu yang demikian perlu dibuktikan, dan sampai saat ini belum ada bukti yang bisa men-judge demikian (Wawancara dengan Rahman pengurus kamar santri Pondok Pesantren al-Hikam, Bangkalan Madura, tanggal 16 Mei 2018). 
Berdasarkan pemaparan Kyai Fathurrohim, beliau menyatakan bahwa memang pesantren menjadi salah satu lembaga yang cukup riskan terkena virus homoseksual, karena adanya faktor-faktor "tertentu", yang salah satunya adanya pemisahan antara asrama putra dan putri, dan yang demikian kadangkala berjauhan lokasi. Belum lagi adanya sekat-sekat yang kuat antara dunia santri putra dan putri menjadi "fenomena faktor penyebab" yang terjadi di pesantren (Wawancara dengan Kyai Fathurrohim Abdur Rahman, di Pondok Pesantren al-Hikam, Bangkalan Madura, tanggal 15 Mei 2018)

Namun dalam hal ini Kyai Fathurrohim Abdur Rahman meyakini bahwa disebabkan Pondok Pesantren al-Hikam ini merupakan pondok yang satu area asrama "tidak berjauhan" antara asrama putra dan putri. Santri putra dan putri masih bisa berinteraksi meski ada batasan-batasan tertentu. Santri putra juga pastinya masih bisa melihat santri putri meski dari jauh atau sebaliknya, kondisikondisi demikian dirasa oleh sang ustadz, mampu meminimalisir perilaku homoseks di pesantren al -Hikam. Hal yang demikian pula yang menjadi alasan bahwa di Pesantren al-Hikam perilaku yang cenderung ke sana (homoseks) minim terjadi (Wawancara dengan Kyai Fathurrohim Abdur Rahman, di Pondok Pesantren al-Hikam, Bangkalan Madura, tanggal 15 Mei 2018).

Pernyataan Kyai Fathurrohim dipertegas oleh pernyataan ustadz Abdul Basith yang mengatakan bahwa: selama mengajar di pesantren, tidak pernah ada hukuman yang diberikan kepada santri yang berbuat mesum sesama jenis. Baik yang ada pada santri putra maupun santri putri. Semuanya berjalan seperti biasanya, tidak ada perilaku-perilaku aneh-aneh yang dilakukan para santri, terkhusus homoseks ini (Wawancara dengan Ustadz Abdul Basith, di Pengrus Kesantrian Pondok Pesantren al-Hikam, Bangkalan Madura, tanggal 16 Mei 2018)

Harapannya pula, kesemua itu bersifat murni dan natural, artinya memang benar-benar tidak ada perilaku Homoseksual yang ada di pesantren, khawatirnya secara kasat mata tidak ada, tetapi sesungguhnya di dalamnya perilaku itu ada, tetapi bersifat tersembunyi. Namun sang Ustadz Abdul Basith tetap meyakini 
sepenuhnya bahwa perilaku homoseksual santri di Pesantren alHikam tidak terjadi, apalagi sampai berhubungan badan antar santri sejenis (Wawancara dengan Ustadz Abdul Basith, di Pengrus Kesantrian Pondok Pesantren al-Hikam, Bangkalan Madura, tanggal 16 Mei 2018) .

\section{Upaya Dua Pesantren Tua Bangkalan Madura dalam Meminimalisir Perilaku Homoseksual Santri}

Pada dasarnya para pendiri, pengelola dan founding father Pesantren Salafiyah Kyai Kholil Bangkalan mengetahui benar, bahwa memiliki santri banyak, tentunya akan menghadirkan masalahmasalah kompleks, yang beraneka ragam. Hal yang demikian tidak akan pernah bisa dihindari, karenanya sebagaimana disampaikan di atas "kewaspadaan" menjadi pondasi dasar yang tidak dapat ditinggalkan dan ditanggalkan oleh pesantren.

Pesantren Salafiyah Kyai Kholil Bangkalan selalu memiliki "tameng" untuk menjaga dirinya agar tetap mulia, dan jauh dari hal-hal yang tidak sepantasnya dilakukan di dalamnya. Sehubungan dengan perilaku Homoseksual santri, pihak pesantren Salafiyah Kyai Kholil Bangkalan juga sudah memprediksi jauh-jauh harisebelum maraknya kasus Homoseksual di era kekinian- bahwa dengan jumlah santri yang besar, dan dengan dipisahkannya santri dari lawan jenisnya, atau pula dengan beraneka ragam sifat dan jiwa santri, tentu saja kemungkinan-kemungkinan bisa terjadi. Utamanya kemungkinan munculnya bibit-bibit percintaan sejenis.

Namun dalam hal ini pesantren sudah memiliki antisipasi agar perilaku-perilaku homoseks tidak merebak dan tidak menjangkiti generasi muda yang ada di pesantren. Menurut Ustadz Achmad Hafsin, ada beberapa hal yang dilakukan pihak pesantren dalam mengantisipasi perilaku homoseksual santri, dan itu dibuat beberapa tingkatan, yakni tingkatan awal yakni tatkala santri baru masuk, tingkatan kedua yakni tatkala santri sudah berada di dalam pesantren, dan tingkatan ketiga, tatkala santri sudah mau selesai nyantri (Wawancara dengan ustadz Achmad Hafsin, Sekretaris Ma'had Pondok Pesantren Salafiyah Kyai Kholil Bangkalan, Madura tanggal 10 Mei 2018). Selaras dengan bagan berikut: 


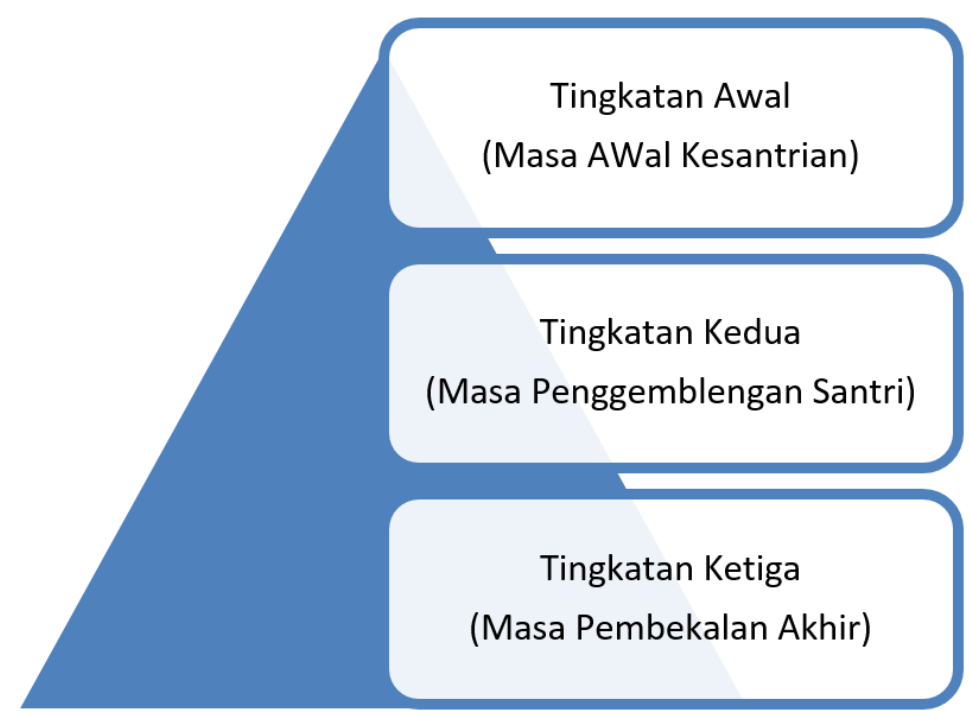

\section{Gambar 3. Tingkatan Pencegahan Dini Perilaku Homosekual Santri}

Pada periode pertama yakni masa awal kesantrian, yakni pada awal masuk mereka ke pesantren, para santri sudah mendapatkan beberapa pengetahuan, di antaranya; 1) Pengetahuan tentang etika nyantri dan segala larangan-larangan yang menyertainya. Termasuk larangan-larangan berbuat asusila di pesantren. Hal tersebut diasumsikan untuk pencegahan awal, agar mereka para santri yang membawa bibit-bibit perilaku homoseks mengerti aturan yang diterapkan di pesantren. 2) Pengetahuan tentang hukumanhukuman yang akan diberikan pada santri, utamanya hukuman yang akan dijatuhkan pada para perilaku Homoseksual santri. Hal tersebut sebagai wacana mereka agar lebih bersikap hati-hati selama nyantri di pesantren. 3) Pengetahuan tentang hilangnya barakah dan kerahmatan Allah poada kaum santri apabila melakukan perilaku-perilaku yang menjurus pada homoseks santri, karena yang demikian sangat tidak diperbolehkan oleh Allah. Hal demikian wajib diketahui santri sejak awal kehadiran di pesantren. 4) Adanya pemahaman untuk tidak membawa alat-alat komunikasi kekinian 
ke pesantren, seperti handphone. Sebab hal-hal yang demkianlah yang menjadi penghalang masuknya ilmu kepada santri.

Kemudian periode kedua atau tingkatan kedua yang dilakukan oleh pihak pesantren yakni tatkala mereka sudah berada di dalam pesantren, dan mereka nyantri mencari ilmu di pesantren. Terkadang kondisi ini justru yang lebih rawan, apalagi dengan waktu belajar yang cukup lama bisa bertahun-tahun, sehingga para santri membutuhkan bimbingan lebih intens agar tidak menyimpang perilakunya. Pada fase kedua ini ada tahapan hukuman dan ada tahapan masukan ilmu.

Tahapan hukuman adalah tahapan dimana pihak pesantren sudah menyiapkan hukuman-hukuman yang akan diberikan kepada para santri yang mbalelo, dari berbagai jenis kenakalan. Utamanya adalah mbalelo berupa berperilaku yang menjurus homoseks. Beberapa hukuman yang diberikan antara lain: a) Digundul kepalanya; b) Dipermalukan di depan banyak santri, dengan cara lari marathon dan dikalungi tulisan yang akan mempermalukan mereka dihadapan banyak santri; c) Dipanggil orang tua ke pesantren; d) Dikembalikan ke orang tua

Adapun tahapan masukan ilmu sebagai pencegahan perilaku menyimpang adalah: a) Pengkajian kitab yang lebih intens, terutama oleh kyai sebagai figur central di pesantren, dan pihak yang diagungkan oleh para santri, sehingga akan mudah mempengaruhi santri; b) Membantu fase penginternalisasian pengkajian kitab kepada santri, sehingga kitab bukan hanya menjadi formalitas belaka, tetapi juga memberikan dampak positif yang bertahan lama kepada santri; c) Pemberian nasehat-nasehat yang menjiwa yang disisipkan setiap pembelajaran di area kepesantrenan. Hal ini karena santri masih banyak membutuhkan bimbingan dan nasehat yang intens.

Adapun tahapan ketiga adalah tahapan pembekalan santri di masa akhir. Dimana pemberlakuan ini diterapkan agar para santri yang akan lulus tetap menjaga diri dari perilaku-perilaku yang kurang etis di mayarakat. Pembekalan ini tidak hanya diberikan kepada santri Tsanawiyah saja tetapi juga kepada santri Aliyah yang akan segera usai masa studinya di pesantren. Salah satu isi dari pembekalan masa 
akhir adalah menjauhi dunia homoseks. Hal ini karena pesantren memahami bahwa dunia luar pesantren akan sangat membayahkan diri dan sifatnya keras, kapanpun dan dimanapun bisa saja alumni pesantren terjerumus pada kehancuran diri.

Pencegahan perilaku menyimpang berupa ketiga tingkatan atau tahapan di atas sudah diberlakukan oleh Pesantren Salafiyah Kyai Kholil Bangkalan secara turun temurun. Selain hal tersebut, pemaksimalan potensi pengurus harian, kamar dan bagian betulbetul ditingkatkan. Artinya, tidak hanya menjadi formalitas nama kepengurusan saja tanpa dijalankan, namun dalam hal ini pengurus betul-betul wajib menjalankan tugasnya, misalnya dengan selalu mengadakan ronda malam, untuk melihat perilaku santri di malam hari.

Adapun upaya peminimalisiran perilaku nganeh-nganehi homoseks santri di Pesantren Al-Hikam Bangkalan, menurut Sang Kyai M Nuruddin A. Rahman, sejak awal mendirikan Pesantren Al-Hikam ini, sudah memprediksi akan dugaan-dugaan yang menyatakan bahwa pesantren itu sangat mudah terjangkiti virus homoseksual. Menurut sang Kyai, hal tersebut tidak bisa dipungkiri, karena banyak anak dan beragam sifat, jiwa dan kebiasaan, serta masing-masing anak membawa masa lalu dari asal daerahnya, sehingga apapun bisa saja terjadi. Selain itu adanya faktor-faktor lain yang bisa saja menjadi pemicu tumbuhkembangnya virus homoseks tersebut, yang kesemua itu memang sejak dini harus diminimalisir pertumbuhannya, agar jangan sampai menjadi penyakit di pesantren, yang pada akhirnya sulit untuk diperbaiki. Hal yang demikian akan sangat membahayakan para santri lain, dan nama baik dari pesantren tu sendiri (Wawancara dengan KH.M. Nuruddin A Rahman, di Pondok Pesantren al-Hikam, Bangkalan Madura, tanggal 15 Mei 2018).

Pesantren-pesantren yang lengah dan tidak terlalu fokus kepada kesantrian, sangat mudah dan rentan "kecolongan" perilaku santri-santri yang menjurus pada penyimpangan. Oleh karenanya semua pesantren idealnya harus terus menggerakkan dan menegakkan kewaspadaan yang utuh, agar virus-virus homoseks santri tidak terjangkiti di area pesantren. 
Namun begitu kata sang Kyai Faturrohim, semua pesantren tentunya sudah memiliki usaha dan upaya untuk menangkal perilaku yang "tidak masuk akal, tetapi nyatanya bisa terjadi tersebut." Di Pesantren al-Hikam itu sendiri ada beberapa upaya yang diberlakukan, yang dibuat beberapa metode; Pertama, metode pengkajian kitab, Kedua, Metode spiritual, Ketiga, Metode hukuman, Keempat, metode konseling, Kelima, metode pencerahan dan pengkayaan jiwa, Keenam, Metode pengawasan tanpa putus.

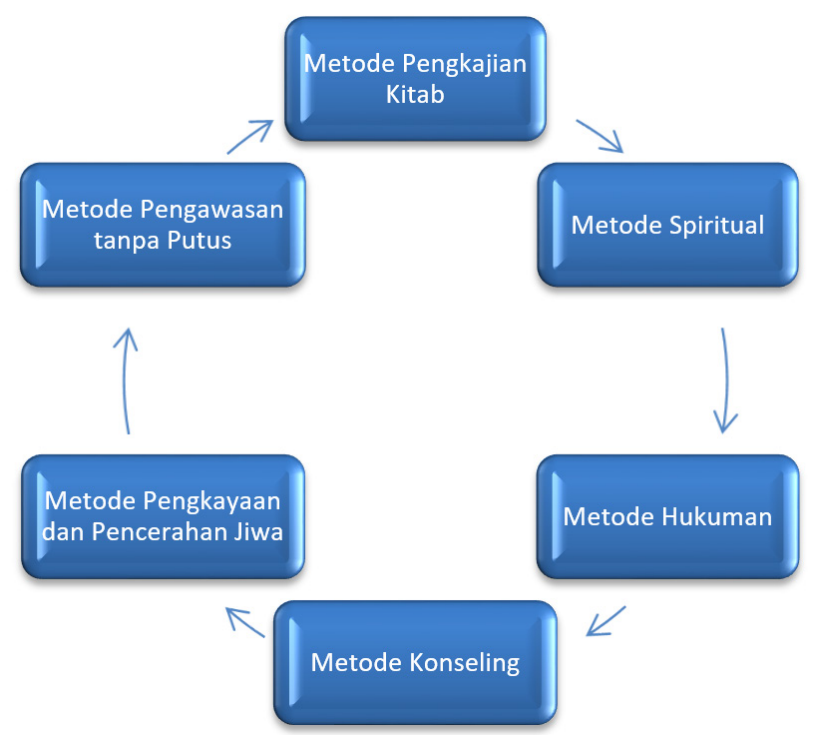

\section{Gambar 5. Metode Pencegahan dan Peminimalisiran Perilaku Homoseks Santri}

Metode Pertama yang diberdayakan di Pesantren Al-Hikam adalah metode pengkajian kitab. Metode ini merupakan pengkayaan kajian kitab, baik itu kitab yang berisi akhlak, tafsir, hadis maupun fiqih. Pengkajian tentang larangan-larangan untuk berbuat dzalim kepada diri sendiri dan orang lain, yang salah satunya adalah homoseks ini juga sengaja diperbanyak pada saat pengkajian kitab. Hal ini sengaja diberlakukan agar para santri mengerti benar bahwa melakukan pendzaliman apapun jenis perbuatannya merupakan perbuatan dosa yang tidak bisa diteruskan dan harus disudahi. Kajian kitab ini aktif dilaksanakan oleh Pesantren Al-Hikam meskipun berbasis modern, yakni pada waktu setelah subuh dan maghrib. 
Metode kedua, metode spiritual. Metode ini merupakan metode berbasis ruhani. Pengkayaan para santri tidak hanya secara pikir tetapi juga kejiwaan, yakni dengan jalan olah batin dan olah rasa. Hal ini sengaja dilakukan oleh pihak pesantren al-Hikam, karena santri harus dicerahkan kejiwaan dan mata batinnya. Karena kejiwaan dan hati inilah yang menjadi pondasi dasar perilaku manusia dan menjadi penentu baik dan buruknya sikap dan perangai manusia. Beberapa kegiatan yang berbasis spiritual di Pesanren al-Hikam antara lain; muhasabah an-nafs, pemaksimalan potensi sholat tahajud, dluha, dan hajat, pengkayaan sholawat kepada Rasul.

Metode ketiga, metode hukuman. Metode ini sengaja diberlakukan di Pesantren al-Hikam sebagai penyeimbang dengan metode spiritual. Artinya, olah jiwa dan rasa itu wajib namun hukuman juga ditegakkan. Pada Pesantren Al-Hikam ini, para santri yang melakukan aniaya terhadap diri sendiri dan orang lain akan tetap dikenakan hukuman, meskipun sekali lagi mereka juga mendapatkan olah jiwa dan rasa. Hukuman-hukuman yang diberlakukan sesuai dengan kadar dari kesalahan yang diperbuat. Terkhusus untuk hukuman bagi para santri yang terindikasi memiliki hukuman sejenis mendapatkan hukuman gundul kepalanya, dipermalukan di ruang publik, sebagai media efek jera. Dengan demikian harapannya mereka tidak melakukan perbuatan yang sama. Namun jika mereka tetap melakukan dan melanjutkan hubungan sejenis setelah diberikannya hukuman, mereka akan dikeluarkan dari Pesantren.

Metode keempat adalah metode konseling. Metode ini diberlakukan oleh Pondok Pesantren al-Hikam sebagai wasilah untuk membantu para santri yang dikategorikan sebagai santri nakal, atau santri bermasalah atau santri yang ber-ulah. Termasuk salah satunya santri yang terindikasi atau ada gejala-gejala berperilaku homoseks. Para santri yang demikian, akan masuk pada ruang konseling, baik setelah atau pun sebelum mendapatkan hukuman dari Pihak Pesantren. Dengan artian, bahwa apabila santri yang terindikasi berperilaku homoseks setelah mendapatkan hukuman maupun belum mendapatkan hukuman tetap akan masuk pada fase konseling. 
Metode kelima, yakni metode pengkayaan dan pencerahan jiwa. Metode ini selaras dengan metode spiritual yang sama -sama bermaksud untuk memurnikan jiwa santri, memutihkan perilaku santri dan meluruskan perangai santri. Pondok Pesantren al-Hikam memberlakukan metode ini agar para santri yang terkena kasus, atau tergolong nakal atau pula yang bermasalah, ternasuk kepada para santri yang terindikasi berperilaku homo, agar mereka bisa selaras kembali pada jalur kebaikan. Beberapa metode yang pengkayaan dan penverahan jiwa yang dilakukan adalah muhasabah, tadzkiroh, halaqah yang berkaitan kejiwaan santri.

Metode keenam, adalah metode pengawasan tanpa putus, metode ini merupakan metode yang bersifat mengawasi secara langsung kegiatan, perangai, dan polah para santri. Beberapa kegiatan tersebut antara lain; mengawasi tatkala santri tidur, yang dilakukan oleh pengurus kamar, dan dewan asatidz, di mana para pengurus kamar akan mengelilingi kamar para santri. Selain itu dalam kegiatan sehari-hari selain malam hari, jasus atau mata-mata akan disebar oleh para asatidz sebagai bentuk pengawasan yang simultan kepada para santri. Harapannya, dengan adanya jasus, para santri yang menyimpang akan segera diobati, dan mendapatkan hukuman yang selaras dengan kesalahannya.

Menurut ustdaz Ustadz Abdul Basith sejatinya penanganan yang diberlakukan di Pesantren al-Hikam ini merupakan penanganan yang biasa-biasa saja, artinya tidak ada yang "khusus", dan diyakini banyak pesantren melakukan hal yang demikian. Meski demikian, pihak pesantren berupaya menerapkan hal yang biasa-biasa saja tersebut tetapi benar-benar dilaksananakan, sehingga harapannya santri yang menyimpang segera lurus kembali (Wawancara dengan Ustadz Abdul Basith, di Pengrus Kesantrian Pondok Pesantren alHikam, Bangkalan Madura, tanggal 16 Mei 2018).

Perilaku Nganeh-nganehi Santri di Dua Pesantren Tua dalam Bingkai Patologi Sosial Kepesantrenan

Berdasarkan hasil penelitian di dua pesantren tua di Bangkalan Madura, apabila dikorelasikan dengan keilmuan Patologi Sosial, 
maka dapat dijabarkan sebagaimana berikut;

Menurut pernyataan Kartini Kartono bahwa patologi sosial adalah semua tingkah laku dan perilaku yang bertentangan dengan asas dan norma kebaikan, kepatutan dan kepantasan dalam masyarakat. Selain itu juga bertentangan dengan hukumhukum yang berlaku baik agama, adat maupun masyarakat (Kartini Kartono, 1992). Definisi lain dinyatakan oleh Adon Nasrullah Jamaludin, yakni: kajian atau pembahasan terhadap gejala sosial atau penyakit sosial, yang menyebabkan kerugian bagi individu tersebut atau orang lain, sehingga dapat menimbulkan keresahan individu atau sosial (Adon Nasrullah Jamaludin, 2016). Demikian pula Paulus Tangdilintin (1999) yang menyatakan bahwa patologi sosial yang merupakan bentuk dari masalah sosial adalah perilakuperilaku yang tidak sesuai dengan nilai-nilai yang ada pada norma sosial dan perilaku yang demikian meresahkan masyarakat (Adon Nasrullah Jamaludin, 2016).

Apabila dilihat dari definisi di atas, dinyatakan bahwa perilaku homoseksual santri atau perilaku yang mengarah ke homoseksual santri meski masih skala ringan sejatinya tetap merupakan perilaku yang "tidak pantas" dan "tidak etis". Hal ini karena tidak selaras dengan nilai moral dan norma positif yang ada di masyarakat (Kamanto Sunarto,1993) Serta menyimpang dari aturan-aturan yang diberlakukan secara hukum agama, positif dan adat. Di sisi lain, perilaku homoseksual akan berdampak negatif baik di masa santri berada di pesantren, maupun setelah mereka ke luar dari pesantren (Kartini Kartono: 1992).

Kondisi yang ada di dua pesantren yakni di Pondok Pesantren Salafiyah Kyai Kholil Bangkalan dan Pondok Pesantren Al-Hikam Madura, yang terdapat para santri yang berperilaku nganeh-nganehi, seperti kobel, mojok, adik-adikan, meski berskala ringan belum sampai pada tahapan making love, tetap saja hal yang demikian menjurus pada perilaku yang tidak etis, dan tidak pantas. Hal yang demikian dapat dikategorikan sebagai bentuk patologi sosial kepesantrenan (Ahmad Mubarok, 2000). Hal ini karena perbuatan tersebut dapat menularkan kepada santri-santri yang "normal" menjadi "tidak normal", dan merugikan para santri lainnya 
atau bahasa lainnya adalah "risih". Mengapa disebut patologi sosial kepesantrenan? Hal ini karena perilaku-perilaku nganeh-nganebi yang menjurus pada homoseksualitas santri dilakukan di wilayah pesantren, dan berstatus menyimpang perilakunya.

Dari hasil penelitian ini dapat disimpulkan bahwa berbagai penyimpangan perilaku dan yang menjurus pada perilaku-perilaku tidak etis dan abnormal yang berada pada wilayah kepesantrenan, maka hal yang demikian dapat dikategorikan sebagai bentuk dari patologi sosial kepesantrenan. Oleh karenanya pihak pesantren harus terus waspada dan mencari bentuk pemecahan atau solusi dari berbagai jenis patologi sosial kepesantrenan ini, termasuk yang salah satunya adalah perilaku-perilaku nganeh-nganebi yang menjurus pada homoseksualitas santri tersebut.

\section{Kesimpulan}

Berdasarkan hasil penelitian di dua pesantren tua yakni di Pondok Pesantren Salafiyah Kyai Kholil Bangkalan dan Pondok Pesantren Al-Hikam Madura, dapatlah diambil kesimpulan bahwa adanya perilaku-perilaku yang nganeh-nganebi yang dikhawatirkan menjurus pada perilaku homoseksual di area kepesantrenan seperti mojok, adik-adikan, kobel, kelon. Meskipun perilakuperilaku tersebut masih berskala ringan, yakni hanya dalam bentuk dolanan (mean: main-main), tidak mengarah pada rasa (feeling) yang menjurus pada perilaku homoseksual yang sebenarnya. Meskipun hal yang demikian tetap tidak menyurutkan pihak dua pesantren untuk melakukkan peminimalisiran perilaku-perilaku yang dikhawatirkan menjurus ke arah homoseksual santri.

Kesimpulan menyatakan bahwa pada substansinya dua pesantren tua melakukan upaya peminimalisiran dengan beberapa tahapan; Pertama, tahapan secara fisik, yakni hukuman-hukuman badaniyyah, Kedua, tahapan secara spiritual, yakni memberikan pendekatan dan pelekatan kepada Allah Ta'ala dengan berbagai kegiatan berbasis spiritual yang berlebih. Ketiga, tahapan secara ta'aqul dan tadabbur, yakni melakukan pengkajian-pengkajian kitab-kitab klasik yang di dalamnya menyoal tentang adab dan akhlak berperilaku. 


\section{Daftar Pustaka}

Elias, Maurice J, ,dkk., 2003. Cara-cara Efektif Mengasah EQ Remaja ; Mengasuh dengan Cinta, Canda dan Disiplin, terj. Ary Nilandari, Bandung: Mizan Media Utama, 2003

Rohmah, Nailil, Homoseksualitas dalam Dunia Pesantren (Studi Tentang Fenomena Lesbianisme di Kalangan Santriwati di Kabupaten Kudus, www.unnes.ac.id

Dzulkarnaen, Iskandar. 2006. Perilaku Homoseksual Pondok Pesantren, Tesis, Yogyakarta: Universitas Gajah Mada

Usman. 2012. Mairil; Phenomena Homoseksualitas di Pesantren, Tesis, Yogyakarta: Universitas Gadjah Mada

Kamiasari, Yuli. 2011. Gambaran Perilaku Mairil dan Nyempet Santri Terhadap Pencegahan HIV/ADIS di Pondok Pesantren, Tesis, Semarang: Universitas Diponegoro

Zuhri, Saifudin. 2007. Dalaq di Pesantren, Tesis, Yogyakarta: Universitas Gadjah Mada

Kartono, Kartini. 2009. Psikologi Abnormal dan Abnormalitas Seksual, Bandung: CV. Mandar Maju

Sunarto, Kamanto. 1993. Pengantar Sosiologi, Jakarta: Lembaga Penerbit FE-UI

Tangdilintin, Paulus. 1999. Masalab-masalab Sosial; Suatu Pendekatan Analisis Sosiologis, Jakarta : Universitas Terbuka

Mubarok, Achmad. 2000. Jiwa dalam Al-Qur'an, Jakarta : Paramadina

Alsa, Asmadi. 2011. Pendekatan kualitatif \& Kuantitatif serta Kombinasinya dalam Penelitian Psikologi, Yogyakarta: Pustaka Pelajar

Bungin ,Burhan. 2007. Penelitian Kualitatif; Komunikasi, Ekonomi, Kebijakan Publik, dan Ilmu Sosial Lainnya, Jakarta: Kencana Sugiyono. 2005. Memahami Penelitian Kualitatif, Bandung : AlFabeta 
Fatchan, Ach. 2015. Metode Penelitian Kualitatif; Pendekatan Etnografi dan Metodologi Untuk Penelitian Ilmu-ilmu Sosial, Yogyakarta: Penerbit Ombak.

artono, Kartini. 1992. Patologi Sosial, Jakarta: Rajawali Press

Jamaludin, Adon Nasrullah. 2016. Dasar-dasar Patologi Sosial, Bandung: CV Pustaka Setia.

Tangdilintin, Paulus. 1999. Masalah-masalah Sosial (Suatu Pendekatan Analisis Sosiologis, Jakarta: Universitas Terbuka

www.news.liputan6.com, yang diakses pada tanggal 12 Februari 2016. Alasan Amerika Melegalkan Pernikahan Sesama Jenis, www.kompasiana.com, 